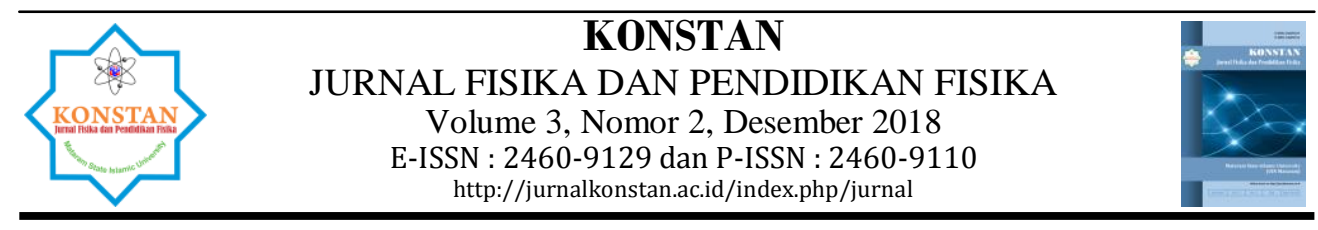

\title{
IDENTIFIKASI AIR TANAH DENGAN METODE GEOLISTRIK RESISTIVITAS KONFIGURASI SCHLUMBERGER DI CANDI DASA PROVINSI BALI
}

\author{
Muwardi Sutasoma ${ }^{1^{*}}$, Anjar Pranggawan $A^{2}$, Meidi Arisalwadi ${ }^{3}$ \\ ${ }^{1}$ Prodi Tadris Fisika FTK UIN Mataram, Mataram, Indonesia, \\ ${ }^{2}$ Prodi Teknik Sipil, Universitas Qamarul Huda Badaruddin Bagu, Praya, Indonesia \\ ${ }^{3}$ Prodi D3 Teknologi pertambangan, Universitas Muhammadiyah Mataram, Indonesia
}

\section{Info Artikel}

Sejarah Artikel:

Diterima Juli 2018

Disetujui Agustus 2018

Dipublikasikan Desember

2018

\section{Kata Kunci:}

Schlumberger, Candi

Dasa, air tanah, Metode resistivitas Sounding, permeabilitas

\begin{abstract}
Abstrak
Pengukuran resistivitas secara sounding telah dilakukan di daerah Candi Dasa (CD), Provinsi Bali. Tujuan penelitian ini adalah mengidentifikasi sumber air tanah baru. Untuk menentukan posisi aquifer air tanah bawah permukaan maka dilakukan pengambilan data sounding di dua titik yaitu CD 1 dan CD 2. Metode yang digunakan adalah metode geolistrik resistivitas Konfigurasi Schlumberger dengan panjang lintasan CD 1 dan CD 2 adalah $150 \mathrm{~m}$ dengan spasi $1 \mathrm{~m}$. Pemrosesan data dengan menggunakan software IP2Win dan Progress 3 untuk memungkinkan penggambaran distribusi resistivitas batuan dalam $1 \mathrm{D}$. Hasil interpretasi menunjukkan bahwa struktur batuan bawah permukaan terdiri dari batuan soil, tuff, lava dan sandy tufa. Hasil interpretasi menunjukkan bahwa lapisan batuan yang terdapat terbentuk karena aktifitas vulkanik yang berasal dari aktifitas Gunung Agung yang berada di Kabupaten Karang Asem. Batuan seperti lava dan tuff adalah batuan yang memiliki porositas yang kecil karena memiliki ukuran butiran yang halus dan kecil, memiliki permeabilitas yang rendah sehingga menyebabkan susah untuk menyimpan dan dan mengalirkan air. Lapisan batuan ini diperkirakan berfungsi sebagai lapisan impermeable dan selanjutnya berfungsi untuk menahan air yang mengalir secara horizontal. Selanjutnya, lapisan batuan sandy tufan yang memiliki porositas dan permeabilitas yang besar karena memiliki butiran batuan yang besar bertugas untuk menyimpan dan mengalirkan air.
\end{abstract}

(C) 2018 Universitas Islam Negeri Mataram

* Corresponding Author: msutasoma@gmail.com

Alamat korespodensi:

Gedung Pasca Sarjana Lantai 3 Kampus 2 UIN Mataram, Jl. Gajah Mada 100 Jempong Mataram, Indonesia

Email: jurnalkonstan@uinmataram.ac.id 


\section{PENDAHULUAN}

Air tanah merupakan salah satu sumber kebutuhan air bagi kehidupan makhluk di muka bumi. Sejak jaman dulu, usaha memanfaatkan dan mengembangkan air tanah telah dilakukan dimulai menggunakan timba (sistem pegas), kemudian berkembang dengan menggunakan teknologi canggih dengan cara mengebor sumur-sumur dalam sampai kedalaman tertentu (Halik and Widodo, 2008). Dengan bertambahnya penduduk, kebutuhan akan air semakin meningkat baik untuk keperluan kehidupan sehari-hari manusia, peternakan maupun pertanian. Masalah ini memerlukan pemecahan berupa pencarian sumber-sumber air tanah untuk memenuhi kebutuhan tersebut. Keberadaan air tanah tergantung pada lokasi geografi , kondisi geologi dan iklim. Daerah yang mengalami kesulitan air tanah dikarenakan kurang adanya lapisan batuan yang mampu menyimpan dan meluluskan air (akuifer), maka perlu dicari sesuatu yang dapat bertindak sebagai akuifer (air celah). Pencarian akuifer untuk mengetahui keberadaan lapisan batuan yang berpotensi mengandung air atau keberadaan serta cebakan air lainnya berupa permeabilitas sekunder yang berpotensi menjadi akuifer produktif, sehingga dapat ditentukan lokasi titik pemboran eksplorasi airtanah-dalam potensial yang sekaligus dapat dikembangkan menjadi sumur produksi,guna memenuhi kebutuhan air baku domestik (Sukadana and Nurdin, 2012). Identifikasi potensi dan keberadaan air tanah dilakukan dengan metode geofisika yaitu metode geolistrik resistivitas Konfigurasi Schlumberger

\section{METODE PENELITIAN}

Untuk mendapatkan informasi bawah permukaan untuk mendapatkan lapisan akuifer di daerah Candi Dasa (CD), penelitian menggunakan metode geolistrik resistivitas sounding dengan konfigurasi schlumberger. Metode ini memanfaatkan sifat massa batuan sebagai penghantar listrik memberikan tahanan jenis atau resistivitas sesuai dengan kandungan material dan kandungan air tanah pada ruang antar pori. Pada konfigurasi Schlumberger idealnya jarak MN dibuat sekecilkecilnya, sehingga jarak MN secara teoritis tidak berubah. Tetapi karena keterbatasan kepekaan alat ukur, maka ketika jarak $\mathrm{AB}$ sudah relatif besar maka jarak MN hendaknya dirubah. Perubahan jarak MN hendaknya tidak lebih besar dari 1/5 jarak AB. Kelemahan dari konfigurasi Schlumberger ini adalah pembacaan tegangan pada elektroda $\mathrm{MN}$ adalah lebih kecil terutama ketika jarak $\mathrm{AB}$ yang relatif jauh, sehingga diperlukan alat ukur multimeter yang mempunyai karakteristik 'high impedance' dengan akurasi tinggi yaitu yang bisa mendisplay tegangan minimal 4 digit atau 2 digit di belakang koma. Atau dengan cara lain diperlukan peralatan pengirim arus yang mempunyai tegangan listrik DC yang sangat tinggi. Sedangkan keunggulan konfigurasi Schlumberger ini adalah kemampuan untuk mendeteksi adanya non-homogenitas lapisan batuan pada permukaan, yaitu dengan membandingkan nilai resistivitas semu ketika terjadi perubahan jarak elektroda MN/2. Pengambilan data geolistrik resistivitas dilakukan pada tanggal 24 April 2010. Adapun titik penelitian dilakukan di dua 
lokasi yaitu CD 1 (50L 0346645 9061164) dan CD 2 (50L 0347046 9060984). Adapun lokasi penelitian dapat dilihat dalam gambar 1.
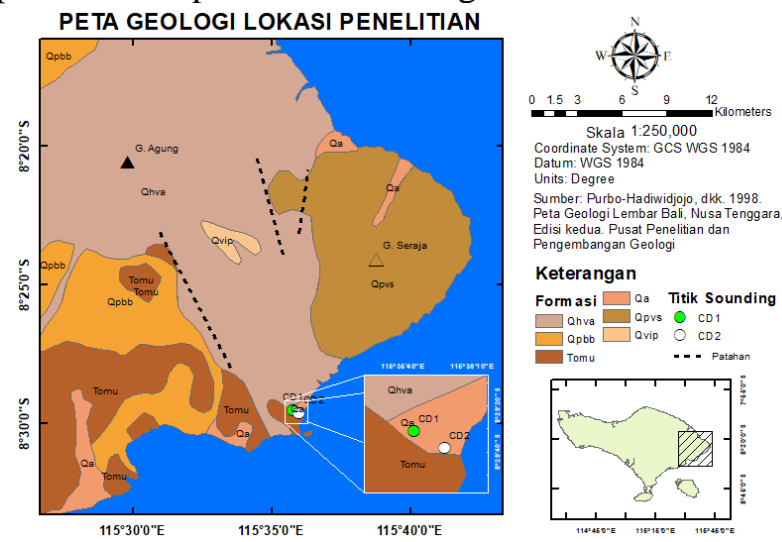

Gambar 1. Peta geologi daerah penelitian (Purbo, Hadiwidjojo,. H. Samodra, 1998)

Pengukuran data metode geolistrik resisitivitas pada dasarnya dilakukan dengan menginjeksikan arus kedalam bumi melalui dua buah elektroda arus (C1 dan C2, Lihat digambar 2) dan selanjutnya mengukur respon beda potensial pada dua buah elektroda potensial (P1 dan P2)(Teti Zubaidah, 2008). Selanjutnya dari data arus (I) dan potensial (P) dilakukan perhitungan untuk mendapatkan nilai resisitivitas semu $\left(\rho_{\alpha}\right)$ sebagai berikut:

$$
\rho_{\alpha=k}
$$

dimana $\mathrm{k}$ adalah faktor geometri yang bergantung pada pengaturan elektroda arus dan potensial.

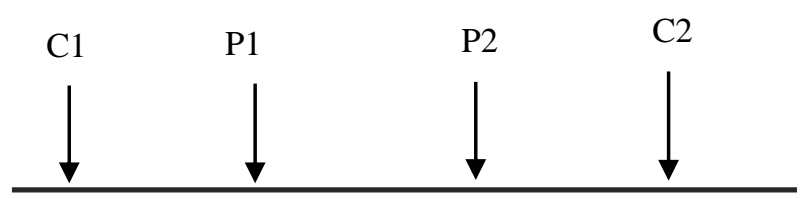

Gambar 2. Susunan 4 Elektroda Sederhana

Dalam survei ini, konfigurasi yang digunakan adalah konfigurasi schlumberger. Konfigurasi ini dilakukan untuk mengetahui lapisan bawah permukaan dalam sounding.

Susunan elektroda dari konfigurasi schlumberger dapat dilihat dalam gambar 3. 


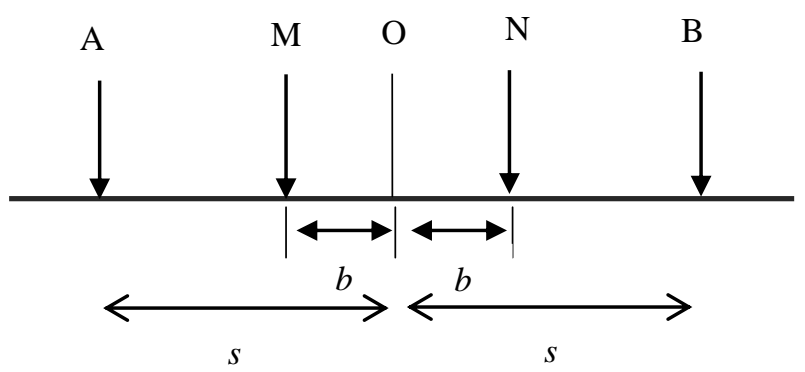

Gambar 2. Susunan elektroda Konfigurasi Schlumberger

\section{HASIL DAN PEMBAHASAN}

Secara geologi, tipe batuan yang ada didaerah penelitian didominasi oleh batuan vulkanik. Batuan yang tergolong dalam batuan vulkanik adalah yaitu tuff, sandy tufa dan lava (Susilo, 2014). Sedangkan nilai permeabilitas daerah penelitian didominasi oleh permeabilitas sedang sampai tinggi. Batuan dengan nilai Permeabilitas tinggi adalah lava dan tuff sedangkan batuan yang memiliki permeabilitas rendah adalah sandy tufa dan soil . Lapisan aquifer yang diperkiranakn menyimpan air terdistribusi merata di kedua titik penelitian.

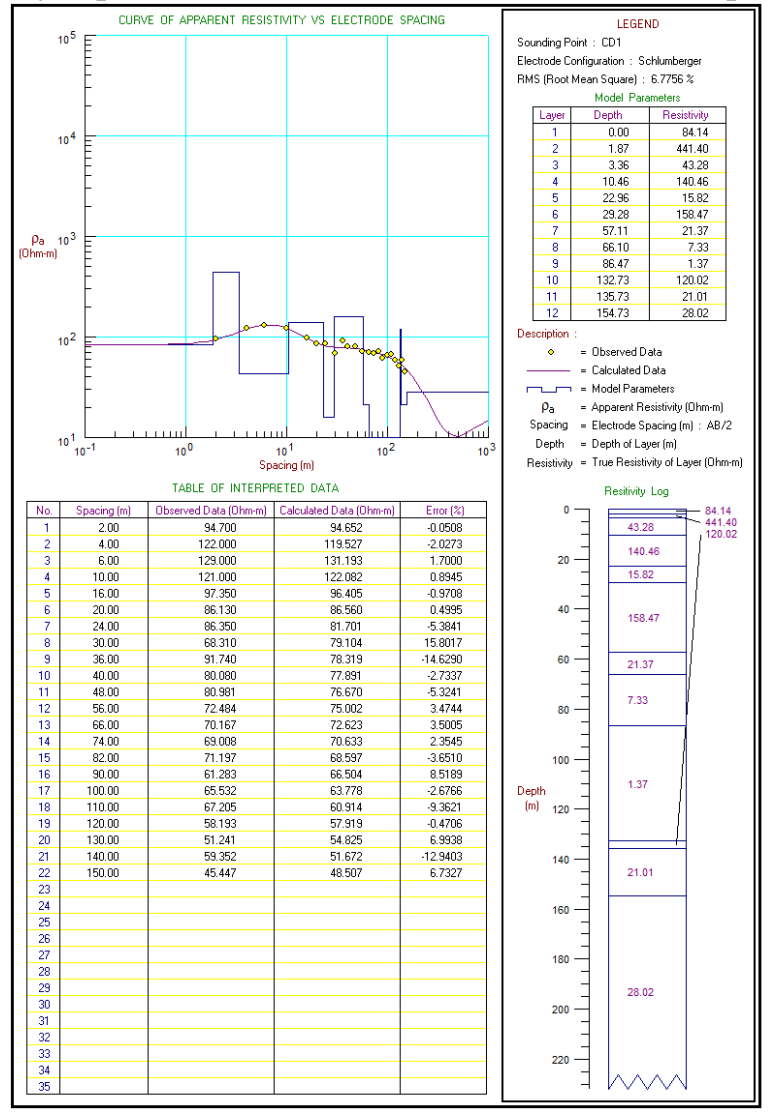


Gambar 3. Hasil dari pemrosesan data geolistrik pada VES 1. Resistivity log pada kolom merah menunjukkan struktur bawah permukaan berdasarkan distribusi resistivitas sampai kedalaman $220 \mathrm{~m}$.

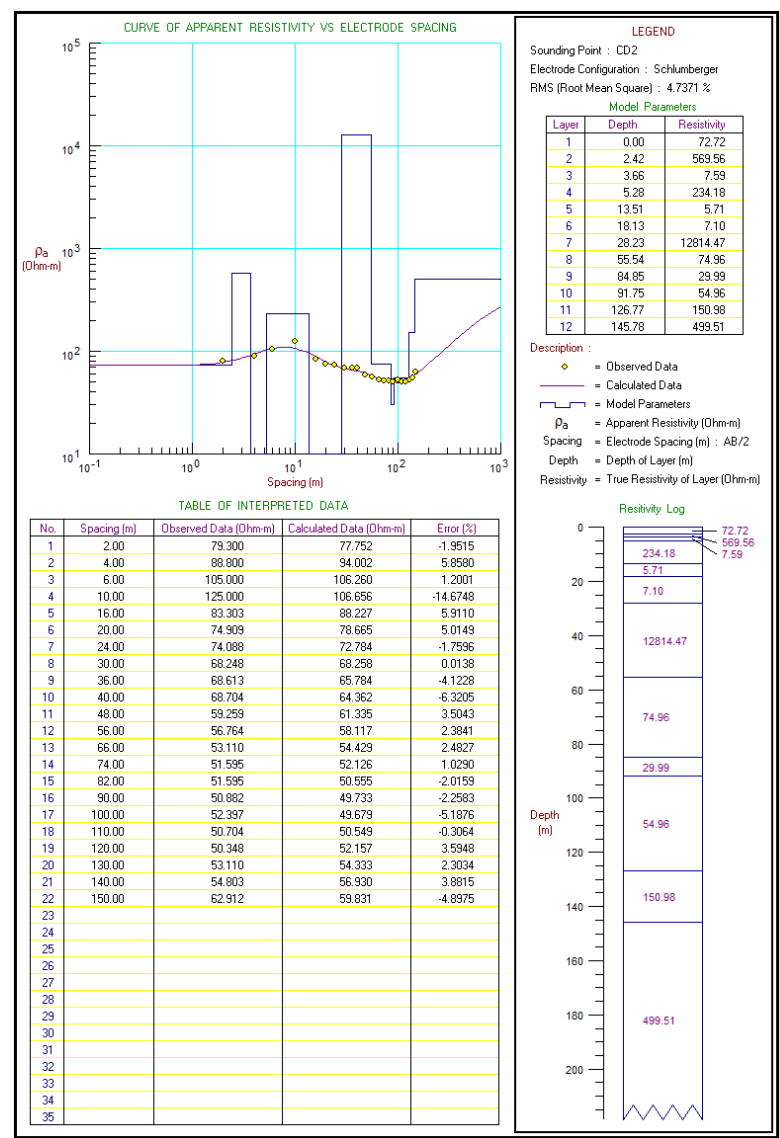

Gambar 4. Hasil dari pemrosesan data geolistrik pada VES 2. Resistivity log pada kolum merah menunjukkan struktur bawah permukaan berdasarkan distribusi resistivitas sampai kedalaman $230 \mathrm{~m}$.

Nilai resistivitas yang didapatkan dari hasill pengukuran bukan resistivitas sebenarnya melainkan resistivitas semu (apparent resistivity). Resistivitas semu merupakan nilai resistivitas bumi yang dianggap homogen, padahal sebenarnya bumi tidak homogen sehingga perlu dilakukan perhitungan secara inversi (Wasis, Sunaryo, Susilo., 2011). Proses inversi ini dilakukan untuk menghilangakn efek geometris agar didapatkan nilai resistivitas sebenarnya (Jayeoba and Oladunjoye, 2015). Dalam penelitian ini, resistivitas semu diproses dengan software IP2WIN dan Progress. Hasil yang diperoleh dalam tampilan grafik dan log resisitivitas karena merepresentasikan setiap titik datum secara sounding. Hasil penelitian dapat dilihat pada gambar 3 dan gambar 4.

Interpretasi hasil pengolahan data telah dilakukan. Setiap titik datum sounding diinterpretasikan jenis-jenis lapisannya untuk mengetahui lithologi dan 
karakteristik akuifernya. Kedalaman lapisan penelitian yang didapatkan pada CD 1 adalah $220 \mathrm{~m}$ sedangkan pada CD 2 adalah $230 \mathrm{~m}$.

Pada titik CD 1, lapisan pertama terdiri dari soil (top soil), selanjutnya diikuti oleh tuff, sandy tufa, tuff, sandy tufa, tuff, sandy tufa (tabel 1).

Tabel 1. Interpretation of subsurface in VES 1

\begin{tabular}{|c|c|c|c|}
\hline Kedalaman $(\mathrm{m})$ & $\begin{array}{c}\text { Ketebalan } \\
(\mathrm{m})\end{array}$ & $\begin{array}{c}\text { Resistivi } \\
\text { tas }(\Omega \mathrm{m})\end{array}$ & Litologi \\
\hline $0-1.87$ & 1.87 & 84.14 & Soil \\
\hline $1.9-3.4$ & 1.49 & 441.40 & Tuff \\
\hline $3.4-10.5$ & 7.10 & 43.28 & Sandy Tufa \\
\hline $10.5-23$ & 12.5 & 140.46 & Tuff \\
\hline $23-29.3$ & 6.32 & 15.82 & Sandy tufa \\
\hline $29.3-57.1$ & 27.82 & 158.47 & Tuff \\
\hline $57.1-66.1$ & 9.01 & 21.37 & Sandy tufa \\
\hline $66.1-86.5$ & 20.37 & 7.33 & Sandu tufa \\
\hline $86.5-132.7$ & 46.26 & 1.37 & Sandy Tufa \\
\hline $132.7-135.7$ & 3 & 120.02 & Tuff \\
\hline $135.7-154.7$ & 19 & 21.01 & Sandy Tufa \\
\hline $154.7-230$ & 75.27 & 28.02 & Sandy Tufa \\
\hline
\end{tabular}

Pada titik CD 2, lapisan pertama terdiri dari soil (top soil), selanjutnya diikuti oleh soil, tuff, soil, sandy tufa, lava, sandy tufa dan tuff (tabel 2).

Tabel 2. Interpretation of subsurface in VES 2

\begin{tabular}{|c|c|c|c|}
\hline $\begin{array}{c}\text { kedalaman } \\
(\mathrm{m})\end{array}$ & $\begin{array}{c}\text { ketebalan } \\
(\mathrm{m})\end{array}$ & $\begin{array}{c}\text { Resistivitas } \\
(\Omega \mathrm{m})\end{array}$ & Litologi \\
\hline $0-2.42$ & 2.42 & 72.72 & Soil \\
\hline $2.42-3.7$ & 1.24 & 569.56 & Tuff \\
\hline $3.7-5.3$ & 1.62 & 7.59 & Sandy tufa \\
\hline $5.3-13.5$ & 8.23 & 234.18 & Tuff \\
\hline $13.5-18.1$ & 4.62 & 5.71 & Sandy tufa \\
\hline $18.1-28.2$ & 10.10 & 7.10 & Sandy Tufa \\
\hline $28.2-55.5$ & 27.31 & 12814.47 & Lava \\
\hline $55.5-84.9$ & 29.31 & 74.96 & Sandy Tufa \\
\hline $84.9-91.8$ & 6.9 & 29.99 & Sandy Tufa \\
\hline $91.8-126.8$ & 35.02 & 54.96 & Sandy Tufa \\
\hline $126.8-145.8$ & 19.01 & 150.98 & Tuff \\
\hline $145.8-215$ & 69.22 & 499.51 & Tuff \\
\hline
\end{tabular}

Akuifer paling baik akan menempati sedimen yang mempunyai porositas tinggi (pasir atau batu pasir) dan mempunyai resistivitas yang rendah (Susilo, 2014).

Dari data yang diperoleh pada gambar 5 (CD1), terdapat 12 lapisan batuan, dimana harga resistivitas mulai dari beberapa ohm meter sampai ratusan ohm meter, sedangkan ketebalan berkisar dari beberapa meter sampai puluhan meter. Kalau dilihat dari hasil pengolahan data, maka air tanah cukup potensial dan terdapat lapisan yang terdiri lapisan sandy tufa. Hal ini karena sandy tufa 
merupakan jenis lapisan yang memiliki porositas tinggi dan resistivitas rendah. Kedalaman sandy tufa pada titik CD 1 adalah $3.4 \mathrm{~m}-10.5 \mathrm{~m}, 13.5 \mathrm{~m}-28.2 \mathrm{~m}$, $57.1 \mathrm{~m}-132.7 \mathrm{~m}$ dan $135.7 \mathrm{~m}-230 \mathrm{~m}$. Namun daerah yang memiliki potensi sebagai akuifer yang paling besar adalah lapisan antara mulai dari 60 meter sampai 125 meter. Lapisan ini bisa jadi dibatasi oleh dua lapisan yang impermeable, dengan $158 \mathrm{ohm}$ meter dan $120 \mathrm{ohm}$ meter.

Data yang diperoleh pada gambar 6 (CD2), didapatkan sebanyak 12 lapisan batuan, dimana harga resistivitas mulai dari beberapa ohm meter sampai ratusan ohm meter, sedangkan ketebalan berkisar dari beberapa meter sampai puluhan meter. Kalau dilihat dari hasil pengolahan data, maka air tanah cukup potensial dan terdapat lapisan yang terdiri lapisan sandy tufa. Hal ini karena sandy tufa merupakan jenis lapisan yang memiliki porositas tinggi dan resistivitas rendah.

Kedalaman sandy tufa pada titik CD 2 adalah $3.7 \mathrm{~m}-5.3 \mathrm{~m}, 13.5 \mathrm{~m}-28.2$ $\mathrm{m}$ dan $55.5 \mathrm{~m}-126.8 \mathrm{~m}$. Namun daerah yang memiliki potensi sebagai akuifer yang paling besar adalah lapisan antara mulai dari 60 meter sampai 125 meter. Lapisan ini bisa jadi dibatasi oleh dua lapisan yang impermeable, dengan $158 \mathrm{ohm}$ meter dan $120 \mathrm{ohm}$ meter. Namun lapisan yang memiliki akuifer yang paling potensial adalah mulai kedalaman $60 \mathrm{~m}$ sampai $125 \mathrm{~m}$. Lapisan ini dibatasi oleh dua lapisan yang impermeabel, dengan bagian atas adalah $12814 \mathrm{ohm}$ meter dan bagian bawah adalah $150 \mathrm{ohm}$ meter. Jika recharge dari lapisan ini ada di pegunungan, bisa dimungkinkan didapatkan sumur artesis.

Dari dua titik yang diteliti, didapatkan bahwa lapisan aquifer berada pada kedalaman antara 60 sampai 125 meter, dengan kedalaman paling baik mulai 90 meter sampai 125 meter.

\section{SIMPULAN DAN SARAN}

Hasil pengolahan data dengan menggunakan metode geolistrik resisitivitas konfigurasi schlumberger untuk memprediksi lapisan air bawah permukaan di daerah Candi Dasa menunjukkan lapisan sandy tuff merupakan lapisan yang memiliki potensi sebagai lapisan akuifer dan kedalamannya antara 60-125 meter. Namun kedalaman terbaik adalah antara 90-125 meter.

\section{UCAPAN TERIMA KASIH}

Ucapan terima kasih penulis sampaikan kepada Bapak Drs. Adi Susilo, Ph.D atas bimbingan dan dukungan dalam penelitian ini.. Terimakasih juga disampaikan kepada Bapak Dr. Bahtiar, M.Pd.Si., yang telah memfasilitasi penulisan artikel pada Jurnal Konstan.

\section{DAFTAR PUSTAKA}

[1] Halik, G. and Widodo, J. (2008) 'Pendugaan Potensi Air Tanah Dengan Metode Geolistrik', Media Teknik Sipil, 113(2), pp. 109-114.

[2] Jayeoba, A. and Oladunjoye, M. A. (2015) '2-D Electrical Resistivity Tomography for Groundwater Exploration in Hard Rock Terrain', 4(4), pp. 156-163.

[3] Purbo, Hadiwidjojo,. H. Samodra, T. . A. (1998) 'Peta Geologi Bersistem 
Indonesia (Bali)', Pusat Penelitian dan Pengembangan Geologi.

[4] Sukadana, I. G. and Nurdin, M. (2012) 'Penentuan Lokasi Potensial Untuk Pemboran Airtanah-Dalam Di Dusun Kutukan, Rejosari, Bantur, Malang, Jawa Timur', Prosiding Seminar Nasional Geologi Nuklir dan Sumber Tambang Tahun 2012, pp. 255-273.

[5] Susilo, A. (2014) 'Subsurface Mapping of Ground Water using Schlumberger Configuration in Upstream of Brantas River, Batu area , East Java , Indonesia', natural B, 2(4), pp. 303-308.

[6] Teti Zubaidah, B. K. (2008) 'Pemodelan Fisika Aplikasi Metode Geolistrik Konfigurasi Schlumberger Untuk Investigasi Keberadaan Air Tanah', Teknologi Elektro, 7(1), pp. 20-24.

[7] Wasis, Sunaryo, Susilo., A. (2011) 'Perunutan Jalur Sesar Lokal di Desa Sri Mulyo Kecamatan Dampit Kabupaten Malang Berdasarkan Data Geofisika', natural B, 1(1), p. 2011.

\section{Biografi Penulis}

Muwardi Sutasoma, S.Si., M.Si., lahir di Dusun Ketewon, Kabupaten Lombok Tengah, NTB pada tanggal 27 Agustus 1990. Pendidikan S-1 di tempuh di Prodi Fisika Universitas Brawijaya Malang dan melanjutkan Pendidikan S-2 di Program Magister Fisika, Kelompok Bidang Minat Geofisika, FMIPA Universitas Brawijaya, Malang. Sekarang penulis merupakan dosen di Prodi Tadris Fisika, FTK, UIN Mataram. Fokus kajian riset selama ini pada manajemen dan mitigasi bencana dengan metode geofisika, terutama dengan near surface geophysics method.

Anjar Pranggawan Azhari, S.Pd., M.Si., lahir di Selong, Kabupaten Lombok Timur, NTB pada tanggal 12 April 1991. Co-author merupakan alumni Prodi Pendidikan Fisika Universitas Negeri Malang dan Magister Ilmu Fisika, Kelompok Bidang Minat Geofisika, FMIPA Universitas Brawijaya, Malang. Saat ini co-author merupakan tenaga pendidik di Prodi S1 Teknik Sipil Universitas Qamarul Huda Badaruddin Bagu (UNIQHBA). Fokus kajian riset selama ini pada struktur geologi khususnya di geothermal terutama dengan metode geopotensial dan penginderaan jauh.

Meidi Arisalwadi,S.Si.,M.Si, lahir di Mantang Kabupaten Lombok Tengah, NTB pada tanggal 11 Mei 1990. Pendidikan S-1 di tempuh di Prodi Fisika FMIPA Universitas Mataram dan melanjutkan Pendidikan S-2 di Program Magister Fisika, Kelompok Bidang Minat Geofisika, FMIPA Universitas Brawijaya, Malang. Saat ini penulis merupakan tenaga pendidik di Prodi D3 Teknologi Pertambangan Universitas Muhammadiyah Mataram. Fokus kajian riset selama ini pada kajian Geofisika dan lingkungan khususnya metode sismik, seismologi terkait gunungapi dan geothermal 